\title{
Revealing Chemopreventive Potential of Active Constituents from Medicinal Herbs Used in Indonesia for Breast Cancer with Particular Molecular Targets
}

\author{
Puguh Indrasetiawan ${ }^{1, *}$, Sari Haryanti ${ }^{3}$, Edy Meiyanto $^{2,4}$ \\ ${ }^{1}$ Department of Pharmaceutical Biology, Faculty of Pharmacy, Universitas Gadjah Mada, Yogyakarta, Indonesia \\ ${ }^{2}$ Cancer Chemoprevention Research Center, Faculty of Pharmacy, Universitas Gadjah Mada, Yogyakarta, Indonesia \\ ${ }^{3}$ Medicinal Plant and Traditional Medicinal Research and Development Centre, Ministry of Health, Tawangmangu \\ Indonesia. \\ ${ }^{4}$ Department of Pharmaceutical Chemistry, Faculty of Pharmacy, Universitas Gadjah Mada, Yogyakarta, Indonesia
}

\begin{abstract}
Breast cancer remains as one of the highest causes of cancer-related deaths in the world, including Indonesia. In spite of following the standard protocol therapy, some patients in developing countries consume medicinal herbs as an alternative, complementary, as well as supportive therapies. Several herbs have been recognized to be used for this purpose. Annona muricata, Curcuma longa, Curcuma zanthorrhiza, Curcuma zedoaria, Phyllanthus urinaria, Gynura procumbens, Garcinia mangostana, Morinda citrifolia, and Nigella sativa are some of the plants used as chemopreventive agents with several formulas. Various types of extracts of Annona muricata show anticancer activities in vitro and in vivo. Curcumin, obtained from Curcuma longa and Curcuma zanthorrhiza, acts as p53 regulator and pro-oxidant in MCF-7 cells and also acts as a fatty acid synthase inhibitor in MDA-MB-231 cells. Xanthorrhizol from Curcuma zanthorrhiza has pro-apoptotic activity via modulation of $\mathrm{Bcl}-2$, p53, and PARP1 protein levels. Curcuma zedoaria contains curcumenone, curcumenol and curdion, which show pro-apoptotic activity in various cell lines and a cancer-induced mouse model. Corilagin and geraniin from Phyllanthus urinaria have different pro-apoptotic effects, in which, the corilagin-caused apoptotic effect is mediated by extrinsic and mitochondrial pathways, whereas geraniin induces apoptosis via ROS-mediated stimulation, both in MCF-7 cells. Thymoquinone from Nigella sativa has been extensively studied for its anticancer activities in recent years. Plants are cultivated, collected and mixed depending on the use as herbal medicines. Active compounds might be formulated if deemed possible. The development of more potential derivatives is also necessary to produce more optimum anti-cancer agents. In conclusion, Indonesian plants and their active constituents show potential activities to be developed as chemopreventive agents.
\end{abstract}

Keywords: Indonesian medicinal herbs, breast cancer, active constituents, molecular targets

\section{INTRODUCTION}

Breast cancer $(\mathrm{BC})$ is still the most frequent cancer among women and on the molecular level, it is a heterogenous disease (Harbeck, et al., 2019). The disease affects 2.1 million women each year, in which also causes the highest cancer-related deaths among women (Bray, et al., 2018). The BC

Submitted: July 3, 2020

Revised: July 23, 2020

Accepted: July 23, 2020

*Corresponding author: puguhindra@ugm.ac.id 
mortality is usually higher in low- and middleincome countries, such as Indonesia, with the mortality rate of $16.6 / 100,000$, a number which is higher than the rest of the world rate: 12.9/100,000 (Youlden, et al., 2014; Coleman, et al., 2008).

In case of medication's decision, histological and molecular characteristics of $\mathrm{BC}$ are mainly influenced. All BCs begin in the terminal duct lobular units of the collecting duct. Based on the histological subtypes, there are preinvasive (ductal carcinoma in situ (DCIS) and lobular carcinoma in situ (LCIS) and invasive (ductal carcinoma no special type (NST) and lobular carcinoma) types of BC (Harbeck, et al., 2019). There are several types of $\mathrm{BC}$ based on its intrinsic subtypes based on the signature of 50-gene expression (PAM50), which are luminal A and luminal B (expressing estrogen receptor, ER), basal-like and human epidermal growth factor receptor 2 (HER-2)-enriched (without ER expression) (Perou, et al., 2000; Cheang, et al., 2015).

Different subtypes of BC display distinct tropism in metastatic patterns (Kennecke, et al., 2010; Dent, et al., 2009). Liver, lung, brain and bone are the common target organs for $\mathrm{BC}$ metastasis. The ER+ tumours have the best prognosis while triple negative (TN) tumours display the worst prognosis (Dent, et al., 2009). The HER2+ tumour is also considered aggressive, however, since there are anti-HER2 therapy, the prognosis has been improving and the patients' lifespan is significantly prolonged (Jin and $\mathrm{Mu}, 2015$ ). Despite of increasing knowledge regarding $\mathrm{BC}$, global prevalence does not come down easily, including in Indonesia (Harbeck, et al., 2019).

The prevalence of $\mathrm{BC}$ tends to increase despite of the availability of more advanced medicines. Patients are often diagnosed at a later stage and are associated with poor prognosis. In spite of being malignant, the early stage of $\mathrm{BC}$ is considered curable in $\sim 70-80 \%$ of the patients, whereas the advanced (metastatic) is not considered curable using currently available medications
(Harbeck, et al., 2019). It is still considered curable, though, if the aim of the medication is to prolong survival and control symptoms with low treatmentassociated toxicity to maintain or improve quality of life.

In Indonesia, the patients suffering from cancer are 35 years of age or older, and they come from various backgrounds. While detecting the cancer early on is extremely important and necessary, most of the patients come to the hospital are already at advanced stage of the disease. This makes the prognosis and treatment outcomes less improving (Lauver, et al., 1987; McPherson, et al., 2000). Breast cancer in particular, is the most predominant cancer among Indonesian women (Dewi, et al., 2019), with $\sim 70 \%$ of BC patients come in at a late stage of the disease (Oemiyati, et al., 2011; Ng, et al., 2011). Empowering Indonesian women to selfexamine their own breast is an extremely important step to positively affecting survival rates (Khokhar, et al., 2013).

The $\mathrm{BC}$, like the other cancers, takes time from being initiated to be invasive, therefore we still have time to prevent the malignancy from going further, through cancer chemoprevention. This effort aims to prevent or delay, inhibit, and/or reverse cancer progression (Steward, et al., 2013; Zubair, et al., 2017). According to Zubair, et al. (2017), there are three aims of cancer prevention, which are primary, secondary and tertiary. The natural products, particularly phytochemicals, have been demonstrating the cancer chemoprevention activities (Janakiram, et al., 2016; Chih, et al., 2013). There are several known substances which are producing multi-effect on $\mathrm{BC}$.

Indonesia has the second-highest biodiversity in the world after Brazil and this provides more chemopreventive agents based on empirical and scientific data. Furthermore, Indonesia has approximately 40,000 endemic plant species including 6,000 medicinal plants (Nugraha, et al., 2011; Yaman, et al., 2014). Since a long time ago, medicinal plant have been used to 
treat maladies including cancer, including by the Indonesian people. Not only in Indonesia, there are medicinal plants that are still being used in the recent days as alternative or combination treatment for breast cancer in Thailand (Poonthananiwatkul, et al., 2015). Numerous plant natural compounds have successfully entered the clinic as cancer chemotheurapetic agents e.g paclitaxel, vinca alkaloids, and homoharringtonine (Martino, et al., 2018; Untch, et al., 2016; Yakhni, et al., 2019).

In this review, we present the potency of the medicinal plants used in Indonesia. We used PubMed search engine to gather the publications with the keywords of each plant combined with "breast cancer" (e.g "Curcuma zedoaria" AND "breast cancer"). We are focusing to collect only the article mentioning these plants related to $\mathrm{BC}$ and not with other cancers. The plants are, in a nonalphabetical order: Annona muricata, Curcuma longa, Curcuma zanthorrhiza, Curcuma zedoaria, Gynura procumbens, Phyllanthus urinaria, Garcinia mangostana, Morinda citrifolia, and Nigella sativa. We believe that by compiling the information regarding the selected plants, it can help to easen the counseling process to the people who are planning and using those plants and willing to have more understanding concerning the plants they are consuming.

\section{Annona muricata}

Annona muricata (Table 1) is used in Nigeria (tropical Africa) Trinidad, Egypt and Jamaica, and the parts used are mainly the leaves, fruit, bark and seeds of the tree (Adewole and Ojewole, 2008; Clement, et al., 2016; Dawood, et al., 2018; Foster, et al., 2017).

There was one case study mentioning that a 66-year old woman with metastatic BC stabilized the disease for five years after the frequent consumption of Annona muricata leaves boiled in water and Capecitabine (Hansra, et al., 2014). The ionic liquid extract of the fruit of Annona muricata exhibited anticancer activity on MCF-7 cells (estrogen-dependent, ER(+)) with comparable value of $\mathrm{IC}_{50}$ with the standard Taxol, while also reduced the growth of the cell by arresting the cell cycle at G0/G1 phase (Daddiouaissa, et al., 2019). The ethanolic extract from the fruit using solid lipid nanoparticles (SLNs) on MCF-7 cells showed that the particular formulation had better efficacy to kill the cancer cells compared to the free extract (without SLNs) (Sabapati, et al., 2019). Aqueous leaf extract from Annona muricata also showed anticancer effect on triple-negative breast cancer (TNBC) MDA-MB-231 cells and ER(+) MCF7 cells, however, cell motility and invasiveness decreased only in TNBC cells. The aqueous extract triggered intrinsic apoptotic pathway through reactive oxygen species (ROS) formation in TNBC cells (Kim, et al., 2018). Nineteen samples of Annona muricata leaves from different locations were screened against MCF-7, MDA-MB-231, and $4 \mathrm{~T} 1$ cells and the results revealed that the aqueous extract collected from Selangor, Malaysia showed the most potent effect with the lowest $\mathrm{IC}_{50}$ values of 220,350 and $250 \mu \mathrm{g} / \mathrm{mL}$ for MCF-7, MDA-MB-231, and $4 \mathrm{~T} 1$ cell lines, respectively (Najmuddin, et al., 2016). The N-butanolic leaf extract of Annona muricata also showed moderate anticancer effect on another metastatic model MDA-MB-435S cells while exhibiting antioxidant activity (George, et al., 2012). Ethanolic extract of Annona muricata leaves prevented cellular proliferation in $\mathrm{BC}$ mice model induced by DMBA and ER(+) T47D cells (Rachmani, et al., 2012; Sulistyoningrum, et al., 2017). Despite showing promising activity in one case mentioned above, more researches are needed to strengthen the base, in particular, finding the responsible compound(s).

\section{Curcuma longa, Curcuma zanthorrhiza, and Curcuma zedoaria}

The three species from the genus Curcuma (Table 2) have been extensively studied and used in Indonesian medicinal plant formulation. Related to BC studies, Curcuma longa has been studied 
Indonesian Journal of Cancer Chemoprevention, October 2020

Table 1. Anti-BC activity of the extracts of Annona muricata.

\begin{tabular}{|c|c|c|c|}
\hline Extracts & Subjects & Key findings & References \\
\hline Aqueous & $\begin{array}{l}\text { MDA-MB-23I cells, } \\
\text { ER(+) MCF-7 cells }\end{array}$ & $\begin{array}{l}\downarrow \text { Cell viability in both cells } \\
\downarrow \text { Cell motility and invasiveness (MDA- } \\
\text { MB-23I cells) } \\
\text { ROS formation triggered MDA-MB-23I } \\
\text { cells intrinsic apoptotic pathway }\end{array}$ & Kim, et al., 2018 \\
\hline $\begin{array}{l}\text { Aqueous (19 } \\
\text { extracts from } \\
\text { various places in } \\
\text { Malaysia) }\end{array}$ & $\begin{array}{l}\text { MCF-7, MDA-MB-23I, } \\
\text { and } 4 \mathrm{TI} \text { cells }\end{array}$ & $\begin{array}{l}\mathrm{IC}_{50}=220,350 \text { and } 250 \mu \mathrm{g} / \mathrm{mL} \text { (MCF-7, } \\
\text { MDA-MB-23I and } 4 \mathrm{TI} \text { cell lines, } \\
\text { respectively) }\end{array}$ & Najmuddin, et al., 2016 \\
\hline $\begin{array}{l}\text { Aqueous (combined } \\
\text { with Capecitabine) }\end{array}$ & $\begin{array}{l}\text { 66-year old woman } \\
\text { with metastatic BC }\end{array}$ & $\begin{array}{l}\text { Cancer stabilized for } 5 \text { years. } \\
\text { First report of clinical effect of Annona } \\
\text { muricata on metastatic } B C \text { patient }\end{array}$ & Hansra, et al., 2014 \\
\hline Ethanolic & $\begin{array}{l}\text { Mouse model induced } \\
\text { by DMBA }\end{array}$ & $\begin{array}{l}\text { Improved histological changes of BC- } \\
\text { induced DMBA mouse model }\end{array}$ & Sulistyoningrum, et al., 2017 \\
\hline Ethanolic & T47D cells & $\begin{array}{l}\mathrm{I}_{50}=17.149 \mu \mathrm{g} / \mathrm{mL} . \\
\uparrow \text { Apoptosis induction of fraction } \mathrm{F} 3\end{array}$ & Rachmani, et al., 2012 \\
\hline $\begin{array}{l}\text { Ethanolic using } \\
\text { SLNs formulation }\end{array}$ & MCF-7 cells & $\begin{array}{l}\text { Efficacy: } \\
\text { SLNs formulation>free extracts }\end{array}$ & Sabapati, et al., 2019 \\
\hline lonic aqueous & MCF-7 cells & $\begin{array}{l}\mathrm{IC}_{50}=4.75 \mu \mathrm{g} / \mathrm{mL}(\text { Taxol }=0.99 \mu \mathrm{g} / \mathrm{mL}) \\
\downarrow \text { Cell cycle in } \mathrm{G} 0 / \mathrm{GI} \text { phase }\end{array}$ & Daddiouaissa, et al., 2019 \\
\hline n-butanolic & MDA-MB-435S cells & $\begin{array}{l}\text { Moderate anticancer activity while } \\
\text { showing antioxidant activity }\end{array}$ & George, et al., 2012 \\
\hline
\end{tabular}

$\downarrow / \uparrow$ : indication of down/up-regulation or activation/suppression or induction/inhibition of a protein and/or pathway.

more extensively than the others, mainly because the curcumin compounds found mainly in Curcuma longa. There are more than 400 publications documented in PubMed with the term "curcumin" in the title combined with "breast cancer", as per this manuscript was prepared.

As for BC studies, there are several findings in the recent years regarding Curcuma longa, mainly its main constituent curcumin and its derivatives. The extract from Curcuma longa root showed anti-metastatic activity through regulating the expression of metastasis markers including $\mathrm{C}-\mathrm{C}$ Chemokine receptor type 7, matrix metalloproteinase 9 and the protooncogenes c-fos and c-jun (Kaya, et al., 2019). Curcumin inhibited the migratory activity of MDA-MB-231 cells through down-regulating the protein expression of $\mathrm{NF}-\kappa \mathrm{Bp} 65$ and reversed doxorubicin resistance in MCF-7 and MDA-MB-231 cells by inhibiting the ATPase activity of ABCB4 (Chiu, et al., 2009; Wen, et al., 2019). Curcumin derivatives (Z)-3- hydroxy-1-(2-hydroxyphenyl)-3-phenylprop-2en-1-one (DK1) and pentagamavunon-1 (PGV-1) exhibited anticancer activities by preventing cell proliferation and promoting apoptosis in vitro and in vivo (Ali, et al., 2017; Lestari, et al., 2019). Curcumin directly targets dual-specificity tyrosineregulated kinase 2 (DYRK2), leading to impaired cancer cell proliferation, has been suggested to interact with CYP17A1, CYP19A1, fatty acid synthase (FAS), and $\alpha 6 \beta 4$ integrin, resulting in cancer cell weakening, thus more prone to the medication (Banerjee, et al., 2018; Castaño, et al., 2019; Fan, et al., 2016; Kim, et al., 2008). Curcumin was suggested to inhibit amino-1-methyl6-phenylimidazo[4,5-b]pyridine (PhIP)-induced DNA adduct formation and DNA double strand breaks with associated decrease in ROS production. The PhIP-DNA formation may cause mutations which in turn leads to DNA damage, chromosome aberrations, and BC (Jain, et al., 2015; Gooderham, et al., 2002; Otsuka, et al., 1996; Wu, et al., 1997; 
Indrasetiawan, et al., 2020

Indones. J. Cancer Chemoprevent., 11(3), 168-186

Table 2. Anti-BC activity of the constituents of Curcuma longa, Curcuma zanthorrhiza, and Curcuma zedoaria.

\begin{tabular}{|c|c|c|c|}
\hline Extracts/compounds & Subjects & Key findings & References \\
\hline ADQ formula & $\begin{array}{l}\text { MDA-MB-23I } \\
\text { cells, } \\
\text { MCF-7 cells }\end{array}$ & $\downarrow$ Caveolin- $\mid$ & Wang, et al., 2018 \\
\hline Aromatic turmerone & $\begin{array}{l}\text { MDA-MB-23I } \\
\text { cells }\end{array}$ & $\begin{array}{l}\downarrow \text { TPA-induced up-regulation of MMP-9 and COX-2 } \\
\downarrow N F-k B, P I 3 K / A k t \text {, and ERKI/2 signaling }\end{array}$ & Park, 2012 \\
\hline $\begin{array}{l}\text { Curcumenone and } \\
\text { Curcumenol }\end{array}$ & MCF-7 cells & $\begin{array}{l}\text { Curcumenon } \mathrm{IC}_{50}=8.3 \pm 1.0 \mu \mathrm{g} / \mathrm{mL} \\
\text { Curcumenol } \mathrm{IC}_{50}=9.3 \pm 0.3 \mu \mathrm{g} / \mathrm{mL} \\
\uparrow \text { Apoptosis induction }\end{array}$ & Hamdi, et al., 2014 \\
\hline Curcumin & $\begin{array}{l}\text { MDA-MB-23I } \\
\text { cells }\end{array}$ & $\begin{array}{l}\text { Targets DYRK } 2 \rightarrow \text { reduced proteasome activity and } \\
\text { impaired cell proliferation. }\end{array}$ & Banerjee, et al., 2018 \\
\hline Curcumin & $\begin{array}{l}\mathrm{NCl}-\mathrm{H} 295 \mathrm{R} \text { cells, } \\
\text { JEG3 cells }\end{array}$ & $\begin{array}{l}\downarrow \text { CYPI7AI } \\
\downarrow \text { CYPI9AI }\end{array}$ & Castaño, et al., 2019 \\
\hline Curcumin & $\begin{array}{l}\text { MDA-MB-23I } \\
\text { cells }\end{array}$ & $\downarrow$ Fatty acid synthase & Fan, et al., 2016 \\
\hline Curcumin & $\begin{array}{l}\text { MDA-MB-23I } \\
\text { cells }\end{array}$ & $\downarrow \alpha_{6} \beta_{4}$ integrin & Kim, et al., 2008 \\
\hline Curcumin & $\begin{array}{l}\text { MCF-IOA } \\
\text { SK-BR-3 cells, }\end{array}$ & $\downarrow$ PhIP-induced cytotoxicityin & Jain, et al., 2015 \\
\hline \multirow[t]{2}{*}{ Curcumin } & $\begin{array}{l}\text { MDA-MB-23I } \\
\text { cells, MDA-MB- } \\
468 \text { cells }\end{array}$ & $\downarrow$ Metastatic potential of both cells & Palange, et al., 2012 \\
\hline & & $\begin{array}{l}\downarrow \text { Autocrine GH-mediated miR- } 182-96-183 \text { cluster } \\
\text { expression stimulation. } \\
\downarrow \text { Autocrine GH-triggered invasion-metastasis }\end{array}$ & \\
\hline Curcumin & T47D cells & $\begin{array}{l}\downarrow \text { EMT activation through inhibiting NF-KB signaling } \\
\text { and miR- } 182-96-183 \text { cluster expression } \\
\uparrow \text { Induced apoptotic cell death by modulating Bcl-2 } \\
\text { family members }\end{array}$ & Coker-Gurkan, 2019 \\
\hline Curcumin & $\begin{array}{l}\text { MDA-MB-23I } \\
\text { cells }\end{array}$ & $\uparrow \mathrm{miR}-34 \mathrm{a}$ & Gallardo, 2020 \\
\hline Curcumin & MCF-7 cells & $\begin{array}{l}\downarrow T P A \\
\uparrow M M P-9\end{array}$ & Kim, et al., 2012 \\
\hline Curcumin & $\begin{array}{l}\text { CML-derived } \\
\text { leukemic cells in a } \\
\text { xenograft model } \\
\text { and in vitro culture } \\
\text { system }\end{array}$ & $\uparrow R O S$ & Larasati, et al., 2018 \\
\hline Curcumin & Mice model of $B C$ & $\begin{array}{l}\text { Treatment with dendrosomal curcumin (DNC): } \\
\uparrow \text { STAT4 } \\
\uparrow \text { IL- I2 } \\
\downarrow \text { STAT3 } \\
\downarrow \text { IL- } 10 \\
\downarrow \text { arginase I }\end{array}$ & Shiri, et al, 2015 \\
\hline Curcumin & $\begin{array}{l}\text { MDA-MB-23I } \\
\text { cells }\end{array}$ & $\downarrow E F G R$ pathway & Sun, et al., 2012 \\
\hline Curcumin & $\begin{array}{l}\text { MDA-MB-23I } \\
\text { cells, MD-MB-468 } \\
\text { cells }\end{array}$ & $\begin{array}{l}\downarrow \text { FABP5 } \\
\downarrow P P A R \beta / \delta\end{array}$ & $\begin{array}{l}\text { Thulasiraman, et al., } \\
2014\end{array}$ \\
\hline Curcumin & $\begin{array}{l}\text { MCF-7 cells } \\
\text { MCF-7 cells, }\end{array}$ & $\begin{array}{l}\uparrow \text { Urokinase-type plasminogen activator } \\
\uparrow \text { Doxorubicin anticancer activity }\end{array}$ & Zong, et al., 2012 \\
\hline $\begin{array}{l}\text { Curcumin }+ \\
\text { Doxorubicin }\end{array}$ & $\begin{array}{l}\text { MDA-MB-23I } \\
\text { cells }\end{array}$ & $\begin{array}{l}\downarrow \text { Doxorubicin efflux } \\
\downarrow \text { ATPase of ABCB4 } \\
\downarrow \text { ALDOA } \\
\downarrow \text { ENO2 } \\
\downarrow \text { LDHA }\end{array}$ & Wen, et al., 2019 \\
\hline $\begin{array}{l}\text { Curcumin }+ \text { Electrical } \\
\text { pulse }\end{array}$ & $\begin{array}{l}\text { MDA-MB-23I } \\
\text { cells }\end{array}$ & $\begin{array}{l}\downarrow \text { LDHB } \\
\downarrow P F K P \\
\downarrow P G M I \\
\downarrow P G A M I \\
\downarrow P G K I\end{array}$ & Mittal, et al., 2020 \\
\hline
\end{tabular}

$\downarrow / \uparrow$ : indication of down/up-regulation or activation/suppression or induction/inhibition of a protein and/or pathway. 
Lauber, et al., 2007). Curcumin is suggested to limit the metastatic potential of adenocarcinoma cell lines SK-BR-3, MDA-MB-231, MDA-MB-468, possibly by altering the expression of adhesion molecules, and the organization and stiffness of the cell cytoskeleton (Palange, et al., 2012). Curcumin also showed to acting on several pathways to directly or indirectly inhibit $\mathrm{BC}$ progression in vitro (Coker-Gurkan, et al., 2019; Gallardo, et al., 2020; Kim, et al., 2012; Larasati, et al., 2018; Shiri, et al., 2015; Sun, et al., 2012; Thulasiraman, et al., 2014; Zhou, et al., 2017; Zong, et al., 2012). The antiproliferative effect of curcumin was seen when combined with other anticancer drugs such as paclitaxel, tamoxifen and docetaxel in vitro (Calaf, et al., 2018; Jiang, et al., 2013; Quispe-Soto, et al., 2016). Several unique preparations of curcumin, such as $\beta$-cyclodextrin-curcumin inclusion complex and electric pulses, helped to enhance curcumin delivery in T47D cells and MDA-MB-231 cells, respectively, thus increased its antiproliverative ability (Kazemi-Lomedasht, et al., 2013; Mittal, et al., 2020). Another less popular compound in Curcuma longa is aromatic turmeron which has been shown to suppress TPA-induced up-regulation of MMP-9 and COX-2 expression by blocking NF$\mathrm{kB}, \mathrm{PI} 3 \mathrm{~K} / \mathrm{Akt}$, and ERK1/2 signaling in human breast cancer cells (Park, et al., 2012). Aside from the basic research, clinical studies showed that curcumin also had a promising future (Martinez, et al., 2018; Saghatelyan, et al., 2020).

Curcuma zanthorrhiza is also known locally in some part of Indonesia as "temulawak". Xanthorrhizol is the most active and abundant compound isolated from the essential oil of its rhizomes (Jantan, et al., 2012). To our knowledge, xanthorrhizol is also the only compound tested in the studies conducted on $\mathrm{BC}$ in vitro. It is been reported that the compound exerted anticancer activities on MCF-7 cells, YMB-1 cells and MDAMB-231 cells (Anggakusuma, et al., 2009; Cheah, et al., 2006; Cheah, et al., 2008; Udin 2013). When it was combined with curcumin, xanthorrhizol showed synergistic inhibitory growth inhibitory effect to MDA-MB-231 cells (Cheah, et al., 2009). To our knowledge, based on the specific keywords on PubMed (either "xanthorrhizol", "Curcuma xanthorrhiza", "Curcuma zanthorrhiza", combined with "breast cancer"), as this manuscript was being written, there has been no new publications in past 5 years.

Curcuma zedoaria is also known as white turmeric or "temu putih" in Indonesia. The plant has been used since long time ago, even it is featured in Ayurveda and has been used traditionally to treat dyspepsia, menstrual disorders, vomiting and cancer (Lobo, et al., 2009). Ether extract of Curcuma zedoaria inhibited progression of MDAMB-231 cells by arresting G0/G1 phase of cell cycle (Gao, et al., 2014). Hamdi (2014) tested the hexane, dichloromethane, ethyl acetate, methanol, and the methanol-Soxhlet extracts of Curcuma zedoaria rhizomes and found that curcumenone and curcumenol showed strong anticancer activity on MCF-7 cells. Curdione, one of the main constituents in Curcuma zedoaria, was reported to inhibit proliferation of BC cells in vivo and in vitro, possibly by inducing apoptosis via increased expression of cleaved caspase-3, caspase-9 and Bax (Li, et al., 2014). Apart from India, where the traditional use of Curcuma zedoaria is well documented (Lobo, et al., 2009), the plant is also used in China as part of traditional Chinese medicine (TCM). One of the TCM formulas containing Curcuma zedoaria is Ai Du Qing (ADQ), which consist of Hedyotis diffusa, Curcuma zedoaria, Astragalus membranaceus, and Glycyrrhiza uralensis. The ADQ was reported to improve chemosensitization of $\mathrm{BC}$ in vitro via the suggested caveolin-1 targeting (Wang, et al., 2018).

\section{Gynura procumbens and Phyllanthus urinaria}

Gynura procumbens and Phyllanthus urinaria (Table 3) have not been caught much attention like Curcuma, regarding their activity as anticancer agent. To our knowledge, there is 
Indrasetiawan, et al., 2020

Indones. J. Cancer Chemoprevent., 11(3), 168-186

Table 3. Anti-BC activity of the constituents of Gynura procumbens and Phyllanthus urinaria.

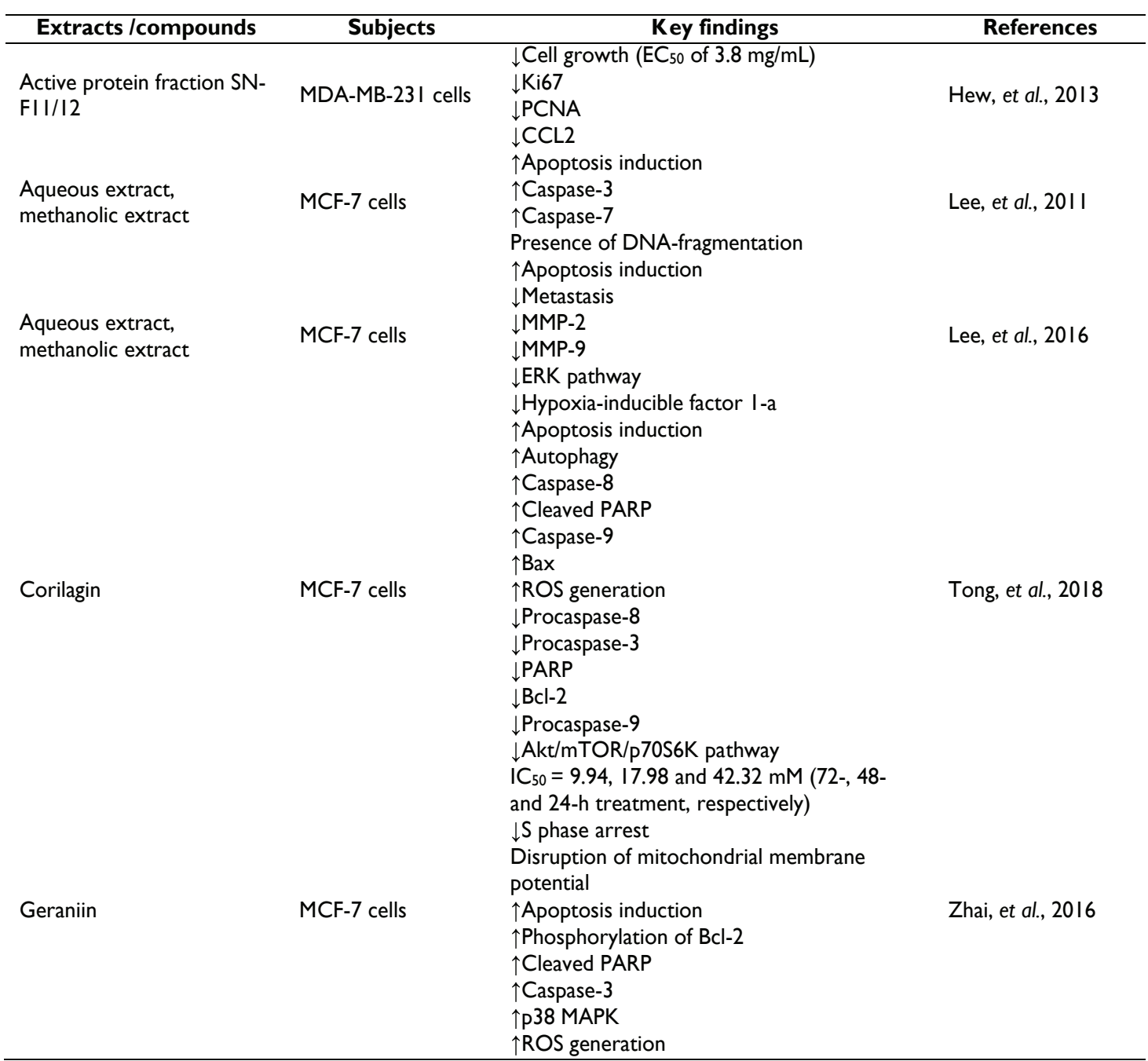

$\downarrow / \uparrow$ : indication of down/up-regulation or activation/suppression or induction/inhibition of a protein and/or pathway. The first four and the last four constituent names were from Gynura procumbens and Phyllanthus urinaria, respectively.

only one BC-related study mentioning Gynura procumbens (Hew, 2013), reporting that the leaves contained defense proteins such as peroxidase, thaumatin-like proteins and miraculin. The active protein fraction SN-F11/12 was reported to inhibit the growth breast cancer in vitro. Phyllanthus urinaria, along with other Phyllanthus (Phyllanthus niruri, Phyllanthus watsonii, and Phyllanthus amarus) was reported to induce apoptosis in concomitant with antimetastatic action with the indication that ERK and hypoxia pathways were the targets (Lee, et al., 2011; Lee, et al., 2016). Corilagin is polyphenol tannic acid obtained from Phyllanthus urinaria selectively induced apoptosis and autophagy in cancer cells but not in healthy cells (Tong, et al., 2018). Geraniin, also present in Phyllanthus urinaria, has been shown to induce apoptosis on $\mathrm{BC}$ in vitro by stimulation of ROS via p38 MAPK signaling (Zhai, et al., 2016). The table below consisted of all publications found in PubMed using either "Gynura procumbens" or "Phyllanthus urinaria" combined with "breast cancer" keywords 
and all of them showed anticancer activity in vitro. Therefore, to our knowledge, no clinical trial has been performed.

\section{Garcinia mangostana}

Garcinia mangostana (mangosteen; Table 4) is known locally in most part of Indonesia as "manggis". The seeds and the pericarps of the fruit have been used as traditional medicine since a long time ago (Ovalle-Magellanes, et al., 2017). There are many reports regarding pharmacological activity of this plant and more than 50 secondary metabolites found in Garcinia mangostana, from which the major bioactive ones are the xanthones $(\alpha$-mangostin and $\gamma$-mangostin are the most abundant ones) (Obolskiy, et al., 2009). Nauman, et al. (2020) screened 9 xanthone constituents from the fruit of mangosteen and reported that $\gamma$-mangostin and $\alpha$-mangostin were the most potent compound on BC cell line MDA-MB-231 by inhibiting CDK2/ CyclinE1 activity. Panaxanthone, a mixture of $\sim 80 \% \alpha$-mangostin and $\sim 20 \% \quad \gamma$-mangostin, has been reported to induce apoptosis, to suppress tumor growth and metastasis in vivo and in vitro (Doi, et al., 2009). The compound $\alpha$-mangostin was suggested to exhibit anticancer activites in vivo and in vitro (Kritsanawong, et al., 2016; Kurose, et al., 2012; Moongkarndi, et al., 2014; Scolamiero, et al., 2018; Shibata, et al., 2011; Suksamrarn, et al., 2006; Taokaew, et al., 2014). The $\gamma$-mangostin was reported to inhibit $\mathrm{BC}$ cell growth by increasing $\alpha$-tubulin acetylation (Yeong, et al., 2020). There are several clinical trials indexed by PubMed with the specific keywords ["Garcinia mangostana" or "mangostin" AND "clinical trial"], however, none of them are related to BC.

\section{Morinda citrifolia}

Morinda citrifolia (noni) is known as "mengkudu" in Indonesia, or "pace" in particular region of Central Java. Almost all parts of the plants have been used as traditional medicine and it is well known for the matured fruit's unpleasant butyric acid smell (Torres, et al., 2017). Noni juice has been sold all over the world and were reported to contain antiproliverative effect on $\mathrm{BC}$ in vivo and in vitro (Clafshenkel, et al., 2012; Taşkin, et al., 2009). Noni oil from the fruit was also reported to contain six compounds, mainly caprylic acid and hexanoid acid, and to have antiproliferative effect in vitro (Piaru, et al., 2012). The methanolic, ethyl acetate and water-ethyl acetate extracts were also found to have anticancer activity on MCF-7 cells and MDAMB-231 cells (Sharma, et al., 2016; Huang, et al., 2016). Two anthraquinones, nordamnacanthal and damnacanthal, were also reported to inhibit $\mathrm{BC}$ progression in vivo and in vitro (Abu, et al., 2018; Aziz, et al., 2014; Aziz, et al., 2016). The search in PubMed using the combination keywords ["Morinda citrifolia" AND "clinical trial"] yielded in less than 10 publications, however, only one is related to $\mathrm{BC}$ and it's not a clinical trial (Marchiori and Zanello, 2017).

\section{Nigella sativa}

Nigella sativa from the family of Ranunculaceae, is ordained as one of super herbs and amazing medicinal plant. It is rich in religious and historical background since hundreds of years ago (Sahak, et al., 2016; Goreja, 2003). Not only historical, there are many scientific reports showing various effects of Nigella sativa including as anti$\mathrm{BC}$ activity. The methanolic extract and the unique formulations induced apoptosis on $\mathrm{BC}$ in vitro (Alhazmi, et al., 2014; Periasamy, et al., 2016; Rohini, et al., 2019). Thymoquinone, an active compound from Nigella sativa, has been shown to exert anticancer activity in vivo and in vitro, either when it worked alone or combined, with several cell signaling cascades involved (Kabil, et al., 2018; Linjawi, et al., 2015; Rajput, et al., 2013; Shanmugam, et al., 2018; Sutton, et al., 2014; Woo, et al., 2011; Woo, et al., 2013). There are more than 50 publications related to the combination of keywords ["Nigella sativa" AND "clinical trial"] and at least 2 clinical trials were performed in the past 5 years with promising results related to $\mathrm{BC}$ (Rafati, et al., 2019; Huseini, et al., 2016). 
Indrasetiawan, et al., 2020

Indones. J. Cancer Chemoprevent., 11(3), 168-186

Table 4. Anti-BC activity of the constituents of Garcinia mangostana constituent.

\begin{tabular}{|c|c|c|c|}
\hline Extracts /compounds & Subjects & Key findings & References \\
\hline$\alpha$-mangostin & T47D cells & $\begin{array}{l}\downarrow \text { Cell proliferation } \\
\uparrow D N A \text { fragmentation } \\
\uparrow \text { Nuclear condensation } \\
\uparrow \text { Cleaved caspase-3 } \\
\uparrow \text { Cleaved caspase-9 } \\
\downarrow B c l-2 \\
\downarrow \text { Mcl-I } \\
\downarrow E R \alpha \\
\downarrow H E R 2 \\
\downarrow P I 3 K \\
\downarrow A k t \\
\downarrow E R K I / 2 \\
\uparrow P-J N K I / 2 \\
\uparrow P-p 38 \\
\uparrow M i t o c h o n d r i a-m e d i a t e d \text { apoptosis induction } \\
\uparrow G I \text { phase arrest } \\
\uparrow P 2 \mid c i p \downarrow\end{array}$ & Kritsanawong, et al., 2016 \\
\hline$\alpha$-mangostin & MDA-MB-23I cells & $\begin{array}{l}\downarrow \text { Cyclins } \\
\downarrow \text { cdc(s) } \\
\downarrow \text { CDKs } \\
\downarrow \text { PCNA }\end{array}$ & Kurose, et al., 201 I \\
\hline$\alpha$-mangostin & $\begin{array}{l}\text { MDA-MB-23I cells, } \\
\text { MCF-7 cells }\end{array}$ & $\begin{array}{l}\uparrow \text { apoptosis induction } \\
\downarrow \text { cell viability } \\
\downarrow \text { cell adhesion } \\
\uparrow \text { suryivability rate in vivo }\end{array}$ & Scolamiero, et al., 2018 \\
\hline$\alpha$-mangostin & $\begin{array}{l}\text { Breast cancer BALB/c } \\
\text { mice model inducted with } \\
\text { BJMC } 3879 \text { luc } 2 \text { cells, } \\
\text { MDA-MB-23 I cells }\end{array}$ & $\begin{array}{l}\uparrow \text { survivability rate in vivo } \\
\uparrow \text { apoptosis induction in vivo } \\
\uparrow \text { caspase-3 } \\
\uparrow \text { caspase- } 9 \\
\downarrow \text { tumor volume in vivo } \\
\downarrow \text { tymph node metastasis in vivo } \\
\uparrow \text { mitochondria-mediated apoptosis induction in } \\
\text { vitro } \\
\uparrow G \mathrm{I}-\text { phase and S-phase suppression in vitro } \\
\downarrow \text { Thr308 in vivo and in vitro }\end{array}$ & Shibata, et al., 201 I \\
\hline$\alpha$-mangostin & BC-I cells & $\mathrm{IC}_{50}=0.92 \mu \mathrm{g} / \mathrm{mL}$ & Suksamrarn, et al., 2006 \\
\hline$\gamma$-mangostin & $\begin{array}{l}\text { MDA-MB-23 I cells, } \\
\text { MCF-7 cells }\end{array}$ & $\begin{array}{l}\text { Discovery and identification of } \gamma \text {-mangostin as } \\
\text { potent and selective SIRT } 2 \text { inhibitor } \\
\uparrow \alpha \text {-tubulin acetylation on both cells } \\
\downarrow \text { Cell proliferation }\end{array}$ & Yeong, et al., 2020 \\
\hline $\begin{array}{l}\alpha \text {-mangostin (bacterial } \\
\text { cellulose films containing } \\
\text { ethanolic extract of the } \\
\text { peel) }\end{array}$ & MCF-7 cells & $\begin{array}{l}\downarrow \text { Cell viability } \\
\downarrow \text { Cell survival rate } \\
\text { Cell morphological change }\end{array}$ & Taokaew, et al., 2014 \\
\hline $\begin{array}{l}\alpha \text {-mangostin and } \gamma- \\
\text { mangostin }\end{array}$ & MDA-MB-23I cells & $\begin{array}{l}\downarrow \text { cell viability in dose-dependent manner } \\
\downarrow C D K 2 / \text { CyclinEI } \\
\uparrow \text { Apoptosis induction }\end{array}$ & Nauman, et al., 2020 \\
\hline $\begin{array}{l}\text { Panaxanthone, }(\sim 80 \% \alpha- \\
\text { mangostin }+\sim 20 \% \gamma- \\
\text { mangostin) }\end{array}$ & $\begin{array}{l}\mathrm{BC} B A L B / c \text { mice model } \\
\text { inducted with BJMC } 3879 \\
\text { cells }\end{array}$ & $\begin{array}{l}\downarrow \text { Tumor suppression } \\
\downarrow \text { Metastasis to lung } \\
\downarrow \text { Metastasis to lymph node } \\
\downarrow \text { PCNA } \\
\downarrow \text { Angiogenenesis }\end{array}$ & Doi, et al., 2009 \\
\hline
\end{tabular}

$\downarrow / \uparrow$ : indication of down/up-regulation or activation/suppression or induction/inhibition of a protein and/or pathway. ${ }^{1}$ The $\mathrm{ED}_{50}$ (median effective dose) is the dose of a medication that produces a specific effect in $50 \%$ of the population that takes that dose (Kenny and McPhee, 2020).

\section{DISCUSSION}

Nine Indonesian medicinal plants used in complementary therapy against breast cancer have shown scientifically that they exert anticancer and chemopreventive activities. Of course, some of the plants were not originated from South East Asia region, let alone Indonesia. However, along with the spread of human population and technological advances, those plants were able to reach Indonesia, 
Table 5. Anti-BC activity of the constituents of Morinda citrifolia.

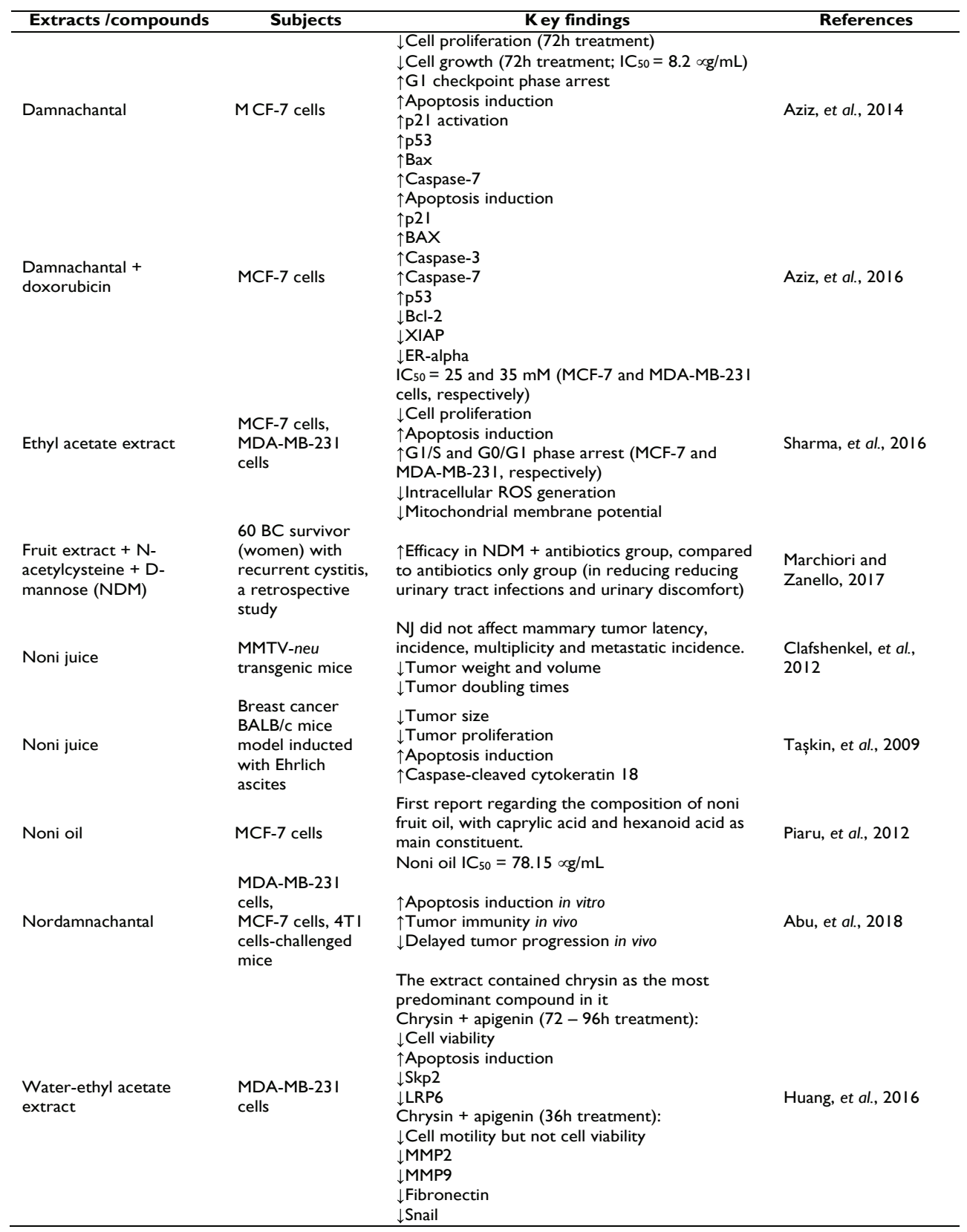

$\downarrow / \uparrow$ : indication of down/up-regulation or activation/suppression or induction/inhibition of a protein and/or pathway.

and were able to be used as traditional medicine in particular. Some of the plants have been more extensively studied than the others (Table 1-6). The plant Curcuma longa, Curcuma zanthorrhiza, Garcinia mangostana, and Nigella sativa have been known to contain active constituent curcumin, xanthorrhizol, $\alpha$-mangostin, and thymoquinone, respectively, as they have been extensively studied in vivo and in vitro, not only in $\mathrm{BC}$ study but also other fields.

For the most part, the selected plants have shown that they induced apoptosis through various 
Table 6. Anti-BC activity of the constituents of Nigella sativa.

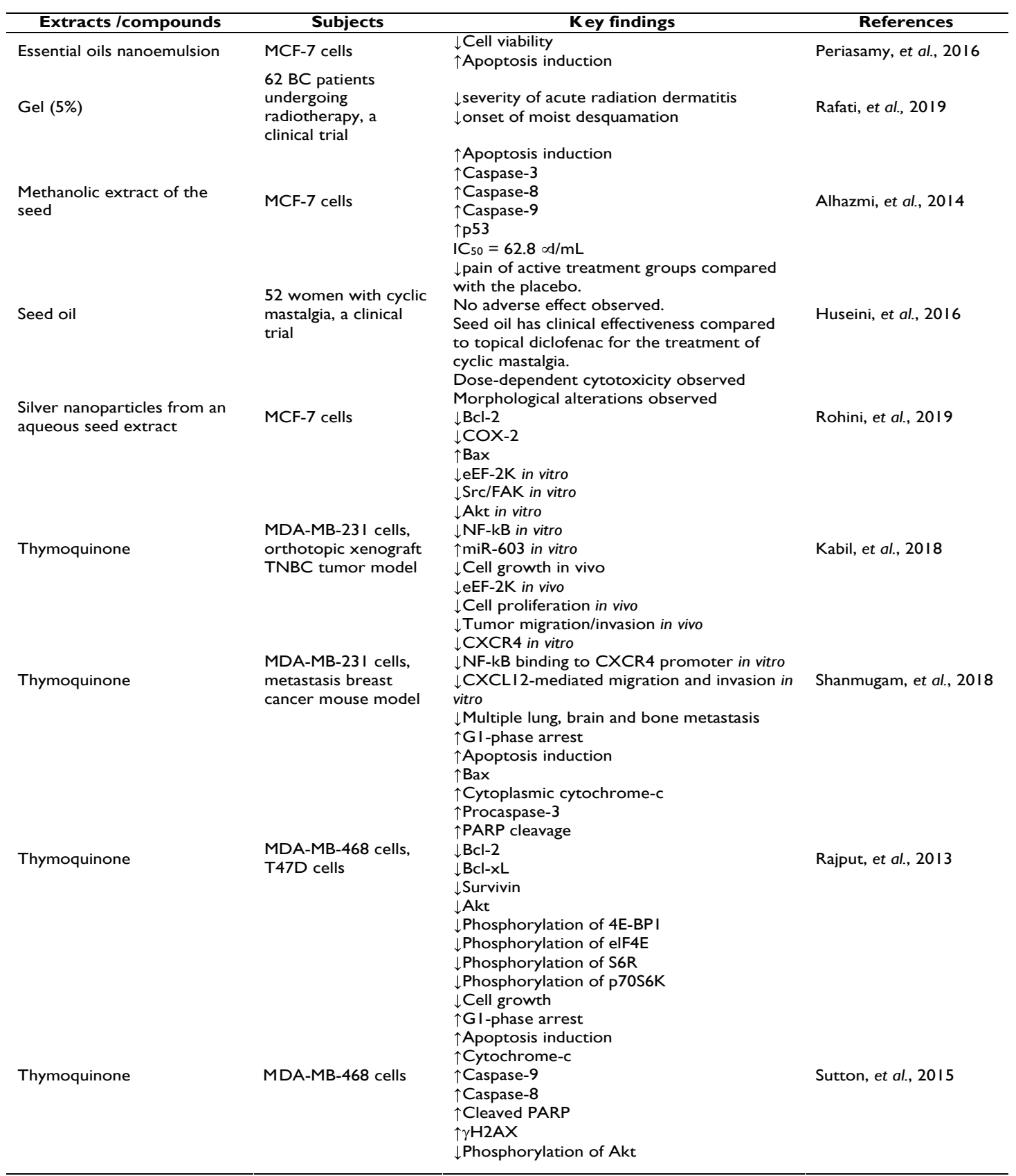

$\downarrow / \uparrow$ : indication of down/up-regulation or activation/suppression or induction/inhibition of a protein and/or pathway.

mechanisms involving the modulation of specific molecular targets e.g. Bcl-2, Bcl-xL, caspase-3, caspase- 8 , caspase- 9 and Bax, either in vivo and/ or in vitro. Some active constituents, like curcumin, induced cell cycle arrest in G2/M phase (Chiu, et al., 2009; Jiang, et al., 2013), whereas thymoquinone induced cell cycle arrest in G1 phase, thus accumulating the cell cycle at subG1 phase (Rajput, et al., 2013; Sutton, et al., 2015; Woo, et al., 2011). The ROS species plays part in cancer develop- 
ment, however, the findings below mentioned interesting results. Corilagin, geraniin and thymoquinone showed to increase ROS production in MCF-7 cells (Tong, et al., 2017; Zhai, et al., 2016; Woo, et al., 2013), where in contrast, Garcinia mangostana crude extract, $\alpha$-mangostin, and Morinda citrifolia fruit extract showed to decrease ROS production (Moongkarndi, et al., 2014; Sharma, et al., 2016). The contradiction showed above suggest that more researches are needed in order to better explain what happens in ROS pathway during the exposure of cancer cells by the selected compounds.

To our knowledge, based on PubMed search we used, only 4 clinical trials related to the reviewed plants and BC. Curcumin (from Curcuma longa) and Nigella sativa extracts were mentioned twice, respectively. (Martinez, et al., 2018; Saghatelyan, et al., 2020; Rafati, et al., 2019; Huseini, et al., 2016). Those trials showed encouraging results from respective plants, opening the possibility to explore the efficacy, safety and toxicity deeper into bigger population. On the other hand, the retrospective clinical study of Morinda citrifolia showed promising results with the combination of the fruit extract with $\mathrm{N}$-acetylcysteine and D-mannose having greater efficacy in reducing urinary tract infections and urinary discomfort compared to antibiotic use only (Marchiori and Zanello, 2017).

There are limitations of our study. Firstly, to our knowledge, the other plants (Annona muricata, Curcuma zedoaria, Gynura procumbens, Phyllanthus urinaria, and Morinda citrifolia) do not have a single prominent compound unlike the rest of the plants. The latter mentioned's reports are mainly from extracts/fractions/unique formulations on $\mathrm{BC}$ in vivo and in vitro. The least reported one, Gynura procumbens, until this manuscript was being finished, has 49 publications in PubMed if we search with a full "Gynura procumbens" term with only one study related to $\mathrm{BC}$ (Hew, et al., 2013). Secondly, this review focused on reviewing the plants and their constituents in BC-related works solely. Therefore, we did not mention the other targets/effects exhibited by the mentioned constituents outside our BC-related scope. We believe by creating such environment, it may help the reader to focus on what's inside the manuscript rather than asking what's not mentioned in this review. Nevertheless, there are still a very wide-open opportunities for the scientists to uncover the responsible compound acting in cancer generally and $\mathrm{BC}$ particularly.

\section{CONCLUSION}

In this review, nine plants i.e Annona muricata, Curcuma longa, Curcuma zanthorrhiza, Curcuma zedoaria, Phyllanthus urinaria, Gynura procumbens, Garcinia mangostana, Morinda citrifolia, and Nigella sativa, have shown to have chemopreventive potential in BC. There are still a lot to understand regarding on how the extracts/compounds work against cancer, therefore more reviews are also needed to reveal their working pattern. Even though most of the plants mentioned here have been extensively inspected, a few of them are not thoroughly traced for their anticancer activity, thus opening a wide opportunity for experimental research and possibly reaching the clinical trial in the future.

\section{REFERENCES}

Abu, N., Zamberi, N.R., Yeap, S.K., Nordin, N., Mohamad, N.E., Romli, M.F., et al., 2018, Subchronic toxicity, immunoregulation and anti-breast tumor effect of Nordamnacantal, an anthraquinone extracted from the stems of Morinda citrifolia L, BMC Complement Altern Med, 18(1), 31.

Adewole, S.O. and Ojewole, J.A.O., 2008, Protective effects of Annona Muricata linn. (Annonaceae) leaf aqueous extract on serum lipid profiles and oxidative stress in hepatocytes of streptozoticin-treated diabetic rats, Afr J Tradit Complement Altern Med, 6(1), 30-41.

Alhazmi, M.I., Hasan, T.N., Shafi, G., Al-Ashaf, A.H., 
Alfawaz, M.A. and Alshatwi, A.A., 2014, Roles of p53 and Caspases in Induction of Apoptosis in MCF- 7 Breast Cancer Cells Treated with a Methanolic Extract of Nigella Sativa Seeds, Asian Pac J Cancer Prev, 115(22), 9655-9660.

Ali, N.M., Yeap, S.K., Abu, N., Lim, K.L., Ky, H., Pauzi, A.Z.M., et al., 2017, Synthetic curcumin derivative DK1 possessed G2/M arrest and induced apoptosis through accumulation of intracellular ROS in MCF-7 breast cancer cells, Cancer Cell Int, 17, 30.

Anggakusuma, Yanti, Lee, M. and Hwang, J.K., 2009, Estrogenic Activity of Xanthorrhizol Isolated from Curcuma xanthorrhiza ROXB, Biol Pharm Bull, 21(11), 1892-1837.

Aziz, M.Y.A., Abu, N., Yeap, S.K., Ho, W.Y., Omar, A.R., Ismail, N.H., et al., 2016, Combinatorial Cytotoxic Effects of Damnacanthal and Doxorubicin against Human Breast Cancer MCF-7 Cells in Vitro, Molecules, 21(9), 1228.

Aziz, M.Y.A., Omar, A.R., Subramani, T., Yeap, S.K., Ho, W.Y., Ismail, N.H., et al., 2014, Damnacanthal is a potent inducer of apoptosis with anticancer activity by stimulating p53 and p21 genes in MCF-7 breast cancer cells, Oncol Lett, 7(5), 1479-1484.

Banerjee, S., Ji, C., Mayfield, J.E., Goel, A., Xiao, J., Dixon, J.E., et al., 2018, Ancient drug curcumin impedes $26 \mathrm{~S}$ proteasome activity by direct inhibition of dual-specificity tyrosine-regulated kinase 2, Proc Natl Acad Sci U S A, 115(32), 8155-8160.

Bray, F., Ferlay, J., Soerjomataram, I., Siegel, R.L., Torre, L.A. and Jemal, A., 2018, Global cancer statistics 2018: GLOBOCAN estimates of incidence and mortality worldwide for 36 cancers in 185 countries, CA Cancer J Clin, 68(6), 394424.

Calaf, G.M., Ponce-Cusi, R. and Carrión, F., 2018, Curcumin and paclitaxel induce cell death in breast cancer cell lines, Oncol Rep, 40(4), 2381-2388.

Castaño, P.R., Parween, S. and Pandey, A.V., 2019, Bioactivity of Curcumin on the Cytochrome P450 Enzymes of the Steroidogenic Pathway, Int
J Mol Sci, 20(18), 4606.

Cheah, Y.H., Azimahtol, H.L.P. and Abdullah, N.R., 2006, Xanthorrhizol Exhibits Antiproliferative Activity on MCF-7 Breast Cancer Cells via Apoptosis Induction, Anticancer Res., 26(6B), 4527 4534.

Cheah, Y.H., Nordin, F.J., Sarip, R., Tee, T.T., Azimahtol, H.L.P., Sirat, H.M., et al., 2009, Combined xanthorrhizol-curcumin exhibits synergistic growth inhibitory activity via apoptosis induction in human breast cancer cells MDAMB-231, Cancer Cell Int., 9, 1.

Cheah, Y.H., Nordin, F.J., Tee, T.T., Azimahtol, H.L.P., Abdullah, N.R. and Ismail, Z., 2008, Antiproliferative Property and Apoptotic Effect of Xanthorrhizol on MDA-MB-231 Breast Cancer Cells, Anticancer Res., 28(6A), 3677-3689.

Cheang, M.C.U., Martin, M., Nielsen, T.O., Prat, A., Voduc, D., Rodriguez-Lescure, A., et al., 2015, Defining Breast Cancer Intrinsic Subtypes by Quantitative Receptor Expression, Oncologist, 20(5), 474-482.

Chih, H.J., Lee, A.H., Colville, L., Binns, C.W. and Xu, D., 2013, A Review of Dietary Prevention of Human Papillomavirus-Related Infection of the Cervix and Cervical Intraepithelial Neoplasia, Nutr Cancer, 65(3), 317-328.

Chiu, T.L. and Su, C.C., 2009, Curcumin inhibits proliferation and migration by increasing the Bax to $\mathrm{Bcl}-2$ ratio and decreasing NF- $\mathrm{kBp} 65$ expression in breast cancer MDA-MB-231 cells, Int $J$ Mol Med, 23(4), 468-75.

Clafshenkel, W.P., King, T.L., Kotlarczyk, M.P., Cline, J.M., Foster, W.G., Davis, V.L., et al., 2012, Morinda citrifolia (Noni) Juice Augments Mammary Gland Differentiation and Reduces Mammary Tumor Growth in Mice Expressing the Unactivated c-erbB2 Transgene, Evid Based Complement Alternat Med, 2012, 487423.

Clement, Y.N., Mahase, V., Jagroop, A., Kissoon, K., Maharaj, A., Mathura, P., et al., 2016, Herbal remedies and functional foods used by cancer patients attending specialty oncology clinics in Trinidad, BMC Compement Altern Med, 16(1), 
399.

Coker-Gurkan, A., Bulut, D., Genc, R., Arisan, E.D., Yerlikaya, P.O. and Palawan-Unsal, N., 2019, Curcumin prevented human autocrine growth hormone $(\mathrm{GH})$ signaling mediated NF-KB activation and miR-183-96-182 cluster stimulated epithelial mesenchymal transition in T47D breast cancer cells, Mol Biol Rep, 46(1), 355-369.

Coleman, M.P., Quaresma, M., Berrino, F., Lutz, J.M., de Angelis, R., Capocaccia, R., et al., 2008, Cancer survival in five continents: a worldwide population-based study (CONCORD), Lancet Oncol, 9, 730-756.

Daddiouaissa, D., Amid, A., Kabbashi, N.A., Fuad, F.A.A., Elnour, A.M. and Epandy, M.A.K.M.S., 2019, Antiproliferative activity of ionic liquidgraviola fruit extract against human $T$ breast cancer (MCF-7) cell lines using flow cytometry techniques, J Ethnopharmacol, 236, 466-473.

Dawood, H.M., Ibrahim, R.S., Shawky, E., Hammoda, H.M. and Metwally, A.M., 2018, Integrated in silico-in vitro strategy for screening of some traditional Egyptian plants for human aromatase inhibitors, J Ethnopharmacol, 224, 359-372.

Dent, R., Hanna. W.M., Trudeau, M., Rawlinson, E., Sun, P. and Narod, S.A., 2009, Pattern of metastatic spread in triple-negative breast cancer, Breast Cancer Res Treat, 115(2), 423-428.

Dewi, T.K., Massar, K., Ruiter, R.A. and Leonardi, T., 2019, Determinants of breast self-examination practice among women in Surabaya, Indonesia: an application of the health belief model, BMC Public Health, 19(1), 1581.

Doi, H., Shibata, M.A., Shibata, E., Morimoto, J., Akao, Y., linuma, M. et al., 2009, Panaxanthone Isolated From Pericarp of Garcinia mangostana L. Suppresses Tumor Growth and Metastasis of a Mouse Model of Mammary Cancer, Anticancer Res, 29(7), 2485-2495.

Fan, H., Liang, Y., Jiang, B., Li, X., Xun, H., Sun, J. et al., 2016, Curcumin inhibits intracellular fatty acid synthase and induces apoptosis in human breast cancer MDA-MB-231 cells, Oncol Rep, 35(5), 2651-2656.
Foster, K., Younger, N., Aiken, W., Brady-West, D. and Delgoda, R., 2017, Reliance on medicinal plant therapy among cancer patients in Jamaica, Cancer Causes Control, 28(11), 1349-1356.

Gallardo, M., Kemmerling, U., Aguayo, F., Bleak, T.C., Muñoz, J.P. and Calaf, G.M., 2020, Curcumin rescues breast cells from epithelial-mesenchymal transition and invasion induced by anti-miR-34a, Int J Oncol, 56(2), 480-493.

Gao, X.F., Lin, Q.L., Li, H.L., Zhang, H.Y., Su, J.Y., Wang, B., Liu, P. and Zhang, A.Q., 2014, Extracts from Curcuma zedoaria Inhibit Proliferation of Human Breast Cancer Cell MDA-MB-231 In Vitro, Evid Based Complement Alternat Med, 2014, 730678.

George, V.C., Kumar, D.R.N., Rajkumar, V., Suresh, P.K. and Kumar, R.A., 2012, Quantitative Assessment of the Relative Antineoplastic Potential of the n-butanolic Leaf Extract of Annona Muricata Linn. in Normal and Immortalized Human Cell Lines, Asian Pac J Cancer Prev, 13(2), 699-704.

Gooderham, N.J., Zhu, H., Lauber, S., Boyce, A. and Creton, S., 2002, Molecular and genetic toxicology of 2-amino-1-methyl-6-phenylimidazo[4,5-b]pyridine (PhIP), Mutat Res, 506507, 91-99.

Goreja, W.G., 2003, Black Seed: Nature's Miracle Remedy, Amazing Herb Press.

Hamdi, O.A.A., Rahman, S.N.S.A., Awang, K., Wahab, N.A., Looi, C.Y., Thomas, N.F., et al,.., 2014, Cytotoxic Constituents from the Rhizomes of Curcuma zedoaria, Scientific World Journal, 2014, 321943.

Hansra, D.M., Silva, O., Mehta, A. and Ahn, E., 2014, Patient with Metastatic Breast Cancer Achieves Stable Disease for 5 Years on Graviola and Xeloda after Progressing on Multiple Lines of Therapy, Breast Cancer Res Treat, 3, 84-87.

Harbeck, N., Penault-Llorca, F., Cortes, J., Gnant, M., Houssami, N., Poortmans, P., et al., 2019, Breast cancer, Nat Rev Dis Primers, 5(1), 66.

Hew, C.S., Khoo, B.Y. and Gam, L.H., 2013, The AntiCancer Property of Proteins Extracted from Gynura procumbens (Lour.) Merr, PLoS One, 8(7), 
e68524.

Huang, C., Wei, Y.X., Shen, M.C., Tu, Y.H., Wang, C.C., et al., 2016, Chrysin, Abundant in Morinda citrifolia Fruit Water-EtOAc Extracts, Combined with Apigenin Synergistically Induced Apoptosis and Inhibited Migration in Human Breast and Liver Cancer Cells, J Agric Food Chem, 64(21), 4235-4245.

Huseini, H.F., Kianbakht, S., Mirshamsi, M.H. and Zarch, A.B., 2016, Effectiveness of Topical Nigella sativa Seed Oil in the Treatment of Cyclic Mastalgia: A Randomized, Triple-Blind, Active, and Placebo-Controlled Clinical Trial, Planta Med, 82(4), 285-288.

Jain, A., Samykutty, A., Jackson, C., Browning, D., Bollag, W.B., Thangraju, M., et al., 2015, Curcumin inhibits PhIP induced cytotoxicity in breast epithelial cells through multiple molecular targets, Cancer Lett, 365(1), 122-131.

Janakiram, N.B., Mohammed, A., Madka. V., Kumar, G. and Rao, C.V., 2016, Prevention and treatment of cancers by immune modulating nutrients, Mol Nutr Food Res, 60(6), 1275-1294.

Jantan, I., Saputri, F.C., Qaisar, M.N. and Buang, F., 2012, Correlation between Chemical Composition of Curcuma domestica and Curcuma zanthorrhiza and Their Antioxidant Effect on Human Low-Density Lipoprotein Oxidation, Evid Based Compement Alternat Med, 2012, 438836.

Jiang, M., Huang, O., Xie, Z., Shen, A., Liu, H., Geng, M., et al., 2013, Curcumin Induces Cell Death and Restores Tamoxifen Sensitivity in the Antiestrogen-Resistant Breast Cancer Cell Lines MCF-7/LCC2 and MCF-7/LCC9, Molecules, 18(1), 701-720.

Jin, X. and Mu, P., 2015, Targeting Breast Cancer Metastasis, Breast Cancer (Auckl), 9(Suppl 1), 2334.

Kabil, N., Bayraktar, R., Kahraman, N., Mokhlis, H.A., Calin, G.A., Lopez-Berestein, G., et al., 2018, Thymoquinone inhibits cell proliferation, migration, and invasion by regulating the elongation factor 2 kinase (eEF-2K) signaling axis in triple-negative breast cancer, Breast Cancer Res Treat, 171(3), 593-605.

Kaya, P., Lee, S.R., Lee, Y.H., Kwon, S.W., Yang, H., Lee, H.W., et al., 2019, Curcumae Radix Extract Decreases Mammary Tumor-Derived Lung Metastasis via Suppression of C-C Chemokine Receptor Type 7 Expression, Nutrients, 11(2), 410.

Kazemi-Lomedasht, F., Rami, A. and Zarghami, N., 2013, Comparison of Inhibitory Effect of Curcumin Nanoparticles and Free Curcumin in Human Telomerase Reverse Transcriptase Gene Expression in Breast Cancer, Adv Pharm Bull, 3(1), 127-130.

Kennecke, H., Yerushalmi, R., Woods, R., Cheang, M.C.U., Voduc, D., Speers, C.H., et al., 2010, Metastatic Behavior of Breast Cancer Subtypes, J Clin Oncol, 28(20), 3271-3277.

Kenny, B.J. and McPhee, A.S., 2020, ED50. [Updated 2019 Feb 6] In: StatPearls [Internet], StatPearls Publishing.

Khokhar, A., 2013, View Point: How to Make Women Familiar with their Breasts?, Asian Pac J Cancer Prev, 14(9), 5539-5542.

Kim, H.I., Huang, H., Cheepala, S., Huang, S. and Chung, J., 2008, Curcumin Inhibition of Integrin (a6B4)-Dependent Breast Cancer Cell Motility and Invasion, Cancer Prec Res (Phila), 1(5), 385-391.

Kim, J.M., Noh, E.M., Kwon, K.B., Kim, J.S., You, Y.O., Hwang, J.K., et al., 2012, Curcumin suppresses the TPA-induced invasion through inhibition of PKCa-dependent MMP-expression in MCF-7 human breast cancer cells, Phytomedicine, 19(12), 1085-1092.

Kim, J.Y., Dao, T.T.P., Song, K., Park, S.B., Jang, H., Park, M.K., et al., 2018, Annona muricata Leaf Extract Triggered Intrinsic Apoptotic Pathway to Attenuate Cancerous Features of Triple Negative Breast Cancer MDA-MB-231 Cells, Evid Based Complement Alternat Med, 2018, 7972916.

Kritsanawong, S., Innajak, S., Imoto, M. and Watanapokasin, R., 2016, Antiproliferative and apoptosis induction of a-mangostin in T47D breast 
cancer cells, Int J Oncol, 48(5), 2155-2165.

Kurose, H., Shibata, M.A., linuma, M. and Otsuki, Y., 2012, Alterations in Cell Cycle and Induction of Apoptotic Cell Death in Breast Cancer Cells Treated with a-Mangostin Extracted from Mangosteen Pericarp, J Biomed Biotechnol, 2012, 672428.

Larasati, Y.A., Yoneda-Kato, N., Nakamae, I., Yokoyama, T., Meiyanto, E. and Kato, J., 2018, Curcumin targets multiple enzymes involved in the ROS metabolic pathway to suppress tumor cell growth, Sci Rep, 8(1), 2039.

Lauber, S.N. and Gooderham, N.J., 2007, The Cooked Meat-Derived Genotoxic Carcinogen 2-Amino-3-Methylimidazo[4,5-b]Pyridine Has Potent Hormone-Like Activity: Mechanistic Support for a Role in Breast Cancer, Cancer Res, 67(19), 9597-9602.

Lauver, D., 1987, Theoretical perspectives relevant to breast self-examination, Adv Nursing Sci, 9(4), 16-24.

Lee, S.H., Jaganath, I.B., Atiya, N., Manikam, R. and Sekaran, S.D., 2016, Suppression of ERK1/2 and hypoxia pathways by four Phyllanthus species inhibits metastasis of human breast cancer cells, J Food Drug Anal, 24(4), 855-865.

Lee, S.H., Jaganath, I.B., Wang, S.M. and Sekaran, S.D., 2011, Antimetastatic Effects of Phyllanthus on Human Lung (A549) and Breast (MCF-7) Cancer Cell Lines, PLoS One, 6(6), e20994.

Lestari, B., Nakamae, I., Yoneda-Kato, N., Morimoto, T., Kanaya, S., Yokoyama, Y., et al., 2019, Pentagamavunon-1 (PGV-1) inhibits ROS metabolic enzymes and suppresses tumor cell growth by inducing $M$ phase (prometaphase) arrest and cell senescence, Sci Rep, 9(1), 14867.

Li, J., Bian, W.H., Wan, J., Zhou, J., Lin, Y., Wang, J.R., et al., 2014, Curdione Inhibits Proliferation of MCF-7 Cells by Inducing Apoptosis, Asian Pac J Cancer Prev, 15(22), 9997-10001.

Linjawi, S.A.A., Khalil, W.K.B., Hassanane, M.M. and Ahmed, E.S., 2015, Evaluation of the protective effect of Nigella sativa extract and its primary active component thymoquinone against DMBA-induced breast cancer in female rats, Arch Med Sci, 11(1), 220-229.

Lobo, R., Prabhu, K.S., Shirwaikar, A. and Shirwaikar, A., 2009, Curcuma zedoaria Rosc. (white turmeric): a review of its chemical, pharmacological and ethnomedicinal properties, J Pharm Pharmacol, 61(1), 13-21.

Marchiori, D. and Zanello, P.P., 2017, Efficacy of $\mathrm{N}$-acetylcysteine, D-mannose and Morinda citrifolia to Treat Recurrent Cystitis in Breast Cancer Survivals, In Vivo, 31(5), 931-936.

Martinez, N., Herrera, M., Frías, L., Provencio, M., Pérez-Carrión, R., Díaz, V., et al., 2018, A combination of hydroxytyrosol, omega-3 fatty acids and curcumin improves pain and inflammation among early stage breast cancer patients receiving adjuvant hormonal therapy: results of a pilot study, Clin Transl Oncol, 21(4), 489-498.

Martino, E., Casamassima, G., Castiglione, S., Cellupica, S., Pantalone, S., Papagni, F., et al., 2018, Vinca alkaloids and analogues as anti-cancer agents: Looking back, peering ahead, Bioorg Med Chem Lett, 28(17), 2816-2826.

McPherson, K., Steel, C.M. and Dixon, J., 2000, ABC of breast disease: Breast cancer-epidemiology, risk factors, and genetics, BMJ, 321(7261), 624-628.

Mittal, L., Aryal, U.K., Camarillo, I.G., Raman, V. and Sundararajan, R., 2020, Effective electrochemotherapy with curcumin in MDA-MB-231-human, triple negative breast cancer cells: A global proteomics study, Bioelectrochemistry, 131, 107350.

Moongkarndi, P., Jaisupa, N., Samer, J., Kosem, N., Konlata, J., Rodpai, E., et al., 2014, Comparison of the biological activity of two different isolates from mangosteen, J Pharm Pharmacol, 66(8), 1171-1179.

Najmuddin, S.U.F.S., Romli, M.F., Hamid, M., Alitheen, N.B. and Rahman, N.M.A.N.A., 2016, Anti-cancer effect of Annona Muricata Linn Leaves Crude Extract (AMCE) on breast cancer 
cell line, BMC Complement Altern Med, 16(1), 311.

Nauman, M.C., Tocmo, R., Vemu, B., Veenstra, J.P. and Johnson, J.J., 2020, Inhibition of CDK2/ CyclinE1 by xanthones from the mangosteen (Garcinia mangostana): a structure-activity relationship study, Nat Prod Res, 21, 1-15.

Ng. C., Pathy, N.B., Taib, N.A., The, Y.C., Mun, K.S., Amiruddin, A., et al., 2011, Comparison of Breast Cancer in Indonesia and Malaysia - A Clinico-Pathological Study Between Dharmais Cancer Centre Jakarta and University Malaya Medical Center, Kuala Lumpur, Asian Pac J Cancer Prev, 12(11), 2943-2946.

Nugraha, A.S. and Keller, P.A., 2011, Revealing Indigenous Indonesian Traditional Medicine: Anti-infective Agents, Nat Prod Commun, 6(12), 1953-1966.

Obolskiy, D., Pischel, I., Siriwatanametanon, N. and Heinrich, M., 2009, Garcinia mangostana L.: a phytochemical and pharmacological review, Phytoter Res, 23(8), 1047-1065.

Oemiyati, R., Rahajeng, E. and Kristanto, A., 2011, Prevalensi Tumor dan Beberapa Faktor yang Mempengaruhinya di Indonesia, Buletin Penelitian Kesehatan, 39(4), 190-204.

Otsuka, C., Miura, K.F., Hatanaka, M., Wakabayashi, K. and Ishidate Jr, M., 1996, Cytogenetic effects of a food mutagen, 2-amino-1-methyl-6-phenylimidazo[4,5-b]pyridine (PhIP), and its metabolite, 2-hydroxyamino-1-methyl-6-phenylimidazo[4,5-b]pyridine ( $\mathrm{N}-\mathrm{OH}-\mathrm{Ph} / \mathrm{P})$, on human and Chinese hamster cells in vitro, Mutat Res, 367(3), 115-121.

Ovalle-Magellanes, B., Eugenio-Pérez, D. and Pedraza-Chaverri, J., 2017, Medicinal properties of mangosteen (Garcinia mangostana L.): a comprehensive update, Food Chem Toxicol, 109(Pt 1), 102-122.

Palange, A.L., Mascolo, D.D., Singh, J, Franceschi, M.S.D., Carallo, C., Gnasso, A., et al., 2012, Modulating the vascular behavior of metastatic breast cancer cells by curcumin treatment,
Front Oncol, 2, 161.

Park, S.Y., Kim, Y.H., Kim, Y.H. and Lee, S.J., 2012, Aromatic-turmerone attenuates invasion and expression of MMP-9 and COX-2 through inhibition of NF-KB activation in TPA-induced breast cancer cells, J Cell Biochem, 113(12), 36533662.

Periasamy, V.S., Athinarayanan, J. and Alshatwi, A.A., 2016, Anticancer activity of an ultrasonic nanoemulsion formulation of Nigella sativa $\mathrm{L}$. essential oil on human breast cancer cells, UItrason Sonochem, 31, 449-455.

Perou, C.M., Sørlie, T., Eisen, M.B., van de Rijn, M., Rees, C.A., Pollack, C.R., et al., 2000, Molecular portraits of human breast tumours, Nature, 406(6797), 747-752.

Piaru, S.P., Mahmud, R., Majid, A.M.S.A., Ismail, S. and Man, C.N., 2012, Chemical composition, antioxidant and cytotoxicity activities of the essential oils of Myristica fragrans and Morinda citrifolia, J Sci Food Agric, 92(3), 593-597.

Poonthananiwatkul, B., Lim, R.H.M., Howard, R.L., Pibanpaknitee, P. and Williamson, E.M., 2015, Traditional medicine use by cancer patients in Thailand, J Ethnopharmacol, 168, 100-107.

Quispe-Soto, E.T. and Calaf, G.M., 2016, Effect of curcumin and paclitaxel on breast carcinogenesis, Int J Oncol, 49(6), 2569-2577.

Rachmani, E.P., Suhesti, T.S. and Widiastuti, A.R., 2012, The Breast of Anticancer from Leaf Extract of Annona muricata Against Cell Line in T47D, Int J Appl Sci Technol, 2(1).

Rafati, M., Ghasemi, A., Saeedi, M., Habibi, E., Salehifar, E., Mosazadeh, M., et al., 2019, Nigella sativa $\mathrm{L}$. for prevention of acute radiation dermatitis in breast cancer: A randomized, double-blind, placebo-controlled, clinical trial, Complement Ther Med, 47, 102205.

Rajput, S., Kumar, B.N.P., Dey, K.K., Pal, I., Parekh, A. and Mandal, M., 2013, Molecular targeting of Akt by thymoquinone promotes G1 arrest through translation inhibition of cyclin D1 and induces apoptosis in breast cancer cells, Life 
Sci, 93(21), 783-790.

Rohini, B., Akhter, T., Waseem, M., Khan, J., Kashif, M. and Hemelatha, S., 2019, AgNPs From Nigella sativa Control Breast Cancer: An In Vitro Study, J Environ Pathol Toxicol Oncol, 38(2), 185-194.

Sabapati, M., Palei, N.N., Kumar, A. and Molakpogu, R.B., 2019, Solid lipid nanoparticles of Annona muricata fruit extract: formulation, optimization and in vitro cytotoxicity studies, Drug Dev Ind Pharm, 45(4), 577-586.

Saghatelyan, T., Yananyan, A., Janoyan, N., Tadevosyan, A., Petrosyan, H., Hovhannisyan, A., et al., 2020, Efficacy and safety of curcumin in combination with paclitaxel in patients with advanced, metastatic breast cancer: A comparative, randomized, double-blind, placebocontrolled clinical trial, Phytomedicine, 70, 153218.

Sahak, M.K.A., Kabir, N., Abbas, G., Draman, S., Hashim, N.H. and Adli, D.S.H., 2016, The Role of Nigella sativa and Its Active Constituents in Learning and Memory, Evid Based Complement Alternat Med, 2016, 6075689.

Scolamiero, G., Pazzini, C., Bonafè, F., Guarnieri, C. and Muscari, C., 2018, Effects of a-Mangostin on Viability, Growth and Cohesion of Multicellular Spheroids Derived From Human Breast Cancer Cell Lines, Int J Med Sci, 15(1), 23-30.

Shanmugam, M.K., Ahn, K.S., Hsu, A., Woo, C.C., Yuan, Y., Tan, K.H.B., et al., 2018, Thymoquinone Inhibits Bone Metastasis of Breast Cancer Cells Through Abrogation of the CXCR4 Signaling Axis, Front Pharmacol, 9, 1294.

Sharma, K., Pachauri, S.D., Ahmad. H,, Arya, A., Biala, P., Agrawal, S., et al., 2016, Anticancer Effects of Extracts from the Fruit of Morinda Citrifolia (Noni) in Breast Cancer Cell Lines, Drug Res (Stuttg), 66(3), 141-147.

Shibata, M.A., linuma, M., Morimoto, J., Kurose, H., Akamatsu, K., Okuno, Y., et al., 2011, a-Mangostin extracted from the pericarp of the mangosteen (Garcinia mangostana Linn) reduces tumor growth and lymph node metastasis in an immunocompetent xenograft model of metastatic mammary cancer carrying a p53 mutation, $B M C$ Med, 9, 69.

Shiri, S., Alizadeh, A.M., Baradaran, B., Farhanghi, B., Shanehbandi, D., Khodayari, S., et al., 2015, Dendrosomal Curcumin Suppresses Metastatic Breast Cancer in Mice by Changing M1/M2 Macrophage Balance in the Tumor Microenvironment, Asian Pac J Cancer Prev, 16(9), 3917-22.

Steward, W.P. and Brown, K., 2013, Cancer chemoprevention: a rapidly evolving field, $\mathrm{Br} \mathrm{J}$ Cancer, 109(1), 1-7.

Suksamrarn, S., Komutiban, O., Ratananukul, P., Chimnoi, N., Lartpornmatulee, N. and Suksamrarn, A., 2006, Cytotoxic Prenylated Xanthones From the Young Fruit of Garcinia mangostana, Chem Pharm Bull (Tokyo), 54(3), 301-305.

Sulistyoningrum, E., Rachmani, E.P.N., Baroroh, H.N. and Rujito L., 2017, Annona muricata Leaves Extract Reduce Proliferative Indexes And Improve Histological Changes In Rat's Breast Cancer, J Appl Pharm, 7(1), 149-155.

Sun, X.D., Liu, X.E. and Huang, D.S., 2012, Curcumin induces apoptosis of triple-negative breast cancer cells by inhibition of EGFR expression, Mol Med Rep, 6(6), 1267-70.

Sutton, K.M., Greenshields, A.L. and Hoskin, D.W., 2014, Thymoquinone, A Bioactive Component of Black Caraway Seeds, Causes G1 Phase Cell Cycle Arrest and Apoptosis in Triple-Negative Breast Cancer Cells with Mutant p53, Nutr Cancer, 66(3), 408-418.

Taokaew, S., Nunkaew, N., Siripong, P. and Phisalaphong, M., 2014, Characteristics and anticancer properties of bacterial cellulose films containing ethanolic extract of mangosteen peel, J Biomater Sci Polym Ed, 25(9), 907-22.

Tașkin, E.I., Akgün-Dar, K., Kapucu, A., Osanç, E., Doğruman, H., Eraltan, H., et al., 2009, Apoptosis-inducing effects of Morinda citrifolia L. and doxorubicin on the Ehrlich ascites tumor in Balb-c mice, Cell Biochem Funct, 27(8), 542546.

Thulasiraman, P., McAndrews, D.J. and Mohiudddin, I.Q., 2014, Curcumin restores sensitivity to 
retinoic acid in triple negative breast cancer cells, BMC Cancer, 14, 724.

Tong, Y., Zhang, G., Li, Y., Xu, J., Yuan, J., Zhang, B., et al., 2018, Corilagin inhibits breast cancer growth via reactive oxygen species-dependent apoptosis and autophagy, J Cell Mol Med, 22(8), 3975-3807.

Torres, M.A.O., Magalhães, I.F.B., Mondêgo-Oliveira R, de Sá, J.C., Rocha, A.L. and Abreu-Silva, A.L., 2017, One Plant, Many Uses: A Review of the Pharmacological Applications of Morinda citrifolia, Phytoter Res, 31(7), 971-979.

Udin Z., 2013, Cytotoxic Activity of Xanthorrhizol from Curcuma Xanthorrhiza Roxb.'s Volatile Oil Toward Ymb-l Breast Cancer Cell, Indonesia J Appl Biochem, 15, 1.

Untch, M., Jackisch, C., Schneeweiss, A., Conrad, B., Aktas, B., Denkert, C., et al., 2016, Nab-paclitaxel versus solvent-based paclitaxel in neoadjuvant chemotherapy for early breast cancer (GeparSepto-GBG 69): a randomised, phase 3 trial, Lancet Oncol, 17(3), 345-356.

Wang, N., Yang, B., Zhang, X., Wang, S., Zheng, Y., Li, X., et al., 2018, Network Pharmacology-Based Validation of Caveolin-1 as a Key Mediator of $\mathrm{Ai}$ Du Qing Inhibition of Drug Resistance in Breast Cancer, Front Pharmacol, 9, 1106.

Wen, C., Fu, L., Huang, J., Dai, Y., Wang, B., Xu, G., et al., 2019, Curcumin reverses doxorubicin resistance via inhibition the efflux function of ABCB4 in doxorubicin-resistant breast cancer cells, Mol Med Rep, 19(6), 5162-5168.

Woo, C.C., Hsu, A., Kumar, A.P., Sethi, G. and Tan, K.H.B., 2013, Thymoquinone Inhibits Tumor Growth and Induces Apoptosis in a Breast Cancer Xenograft Mouse Model: The Role of p38 MAPK and ROS, PLoS One, 8(10), e75356.

Woo, C.C., Loo, S.Y., Gee, V., Yap, C.W., Sethi, G., Kumar, A.P., et al., 2011, Anticancer activity of thymoquinone in breast cancer cells: Possible involvement of PPAR- $\gamma$ pathway, Biochem Pharmacol, 82(5), 464-475.

Wu, R.W., Tucker, J.D., Sorensen, K.J., Thompson, L.H. and Felton, J.S., 1997, Differential effect of acetyltransferase expression on the genotox- icity of heterocyclic amines in $\mathrm{CHO}$ cells, Mutat Res, 390(1-2), 93-103.

Yakhni, M., Briat, A., Guerrab, A.E., Furtado, L., Kwiatkowski, F., Miot-Noirault, E., Cachin, F., Penaul-Llorca, F. and Radosevic-Robin, N., 2019, Homoharringtonine, an approved anti-leukemia drug, suppresses triple negative breast cancer growth through a rapid reduction of anti-apoptotic protein abundance, Am J Cancer Res, 9(5), 1043-1060.

Yaman, E., Elfahmi, Woerdenbag, H.J. and Kayser, O., 2014, Jamu: Indonesian traditional herbal medicine towards rational phytopharmacological use, J Herb Med, 4(2), 51-73.

Yeong, K.Y., Khaw, K.Y., Takahashi, Y., Itoh, Y., Murugaiyah, V. and Suzuki, T., 2020, Discovery of gamma-mangostin from Garcinia mangostana as a potent and selective natural SIRT2 inhibitor, Bioorg Chem, 94, 103403.

Youlden, D.R., Cramb, S.M., Yip, C.H. and Baade, P.D., 2014, Incidence and mortality of female breast cancer in the Asia- Pacific region, Cancer Biol Med, 11, 101-115.

Zhai, J.W., Gao, C., Ma, W.D., Wang, W., Yao, L.P., Xia, X.X., Luo, M., Zu, Y.G. and Fu, Y.J., 2016, Geraniin induces apoptosis of human breast cancer cells MCF-7 via ROS-mediated stimulation of p38 MAPK, Toxicol Mech Methods, 26(5), 311-318.

Zhou, Q.M., Sun, Y., Zhang, H., Chen, Q.L. and Su, S.B., 2017, Curcumin reduces mitomycin $C$ resistance in breast cancer stem cells by regulating Bcl-2 family-mediated apoptosis, Cancer Cell Int, 17, 84.

Zong, H., Wang, F., Fan, Q.X. and Wang, L.X., 2012, Curcumin inhibits metastatic progression of breast cancer cell through suppression of urokinase-type plasminogen activator by NF-kappa B signaling pathways, Mol Biol Rep, 39(4), 48034808.

Zubair, H., Azin, S., Ahmad, A., Khan, M.A., Patel, G.K., Singh, S. and Singh, A.P., 2017, Cancer Chemoprevention by Phytochemicals: Nature's Healing Touch, Molecules, 22(3). 